\title{
Croatian Society for Schizophrenia and Schizophrenia Spectrum Disorders Croatian Medical Association Guidelines for the Treatment of Patients with Schizophrenia
}

\section{Spectrum Disorders during the COVID-19 Pandemic}

\author{
Dalibor Karlović ${ }^{2}{ }^{2}$ Vjekoslav Peitll, ${ }^{1}$ \\ ${ }^{1}$ Department of Psychiatry, University Hospital Center Sestre milosrdnice, Zagreb, Croatia, \\ ${ }^{2}$ Catholic University of Croatia, Zagreb, Croatia
}

The COVID-19 pandemic has raised the question of whether psychiatric patients, especially those with schizophrenia and other psychotic disorders, are more susceptible to SARS-CoV-2 infection. At this point in time we have to emphasize that there is not enough information, especially scientific and evidence-based, to answer this question. The same is true when considering the course of the disease, and also when considering psychopharmacotherapy itself (primarily antipsychotics, but also all other psychopharmaceuticals, that is, mood stabilizers, antidepressants, anxiolytics, hypnotics and pro-cognitive drugs). In case of an infection with a marked clinical presentation that has to be treated with most commonly used drugs (lopinavir / ritonavir, chloroquine / hydroxychloroquine and antibiotics), we provide available information on their potential interactions with psychopharmaceuticals (Table 1). It should be noted that it is advisable to use haloperidol in patients who are agitated and/or aggressive (whether suffering from schizophrenia or some other psychotic disorder or in the case of delirium in otherwise non-psychotic patients), also available in the parenteral formulation. Benzodiazepines, on the other hand, are not recommended to the same extent because of their effects on the respiratory centre, especially when the effect of COVID-19 on the respiratory system is considered.

Below, we provide some general information and recommendations for this population of psychiatric patients.

\section{General information}

To date, the most common symptoms of COVID-19 are: elevated body temperature, fever, shortness of breath, dry cough, chest pain or pressure, fatigue, muscle pain, and difficulty breathing. However, it is important to point out that, with respect to the potential impact of COVID-19 infection on the course and treatment of psychotic disorders, there is at present no clear evidence 


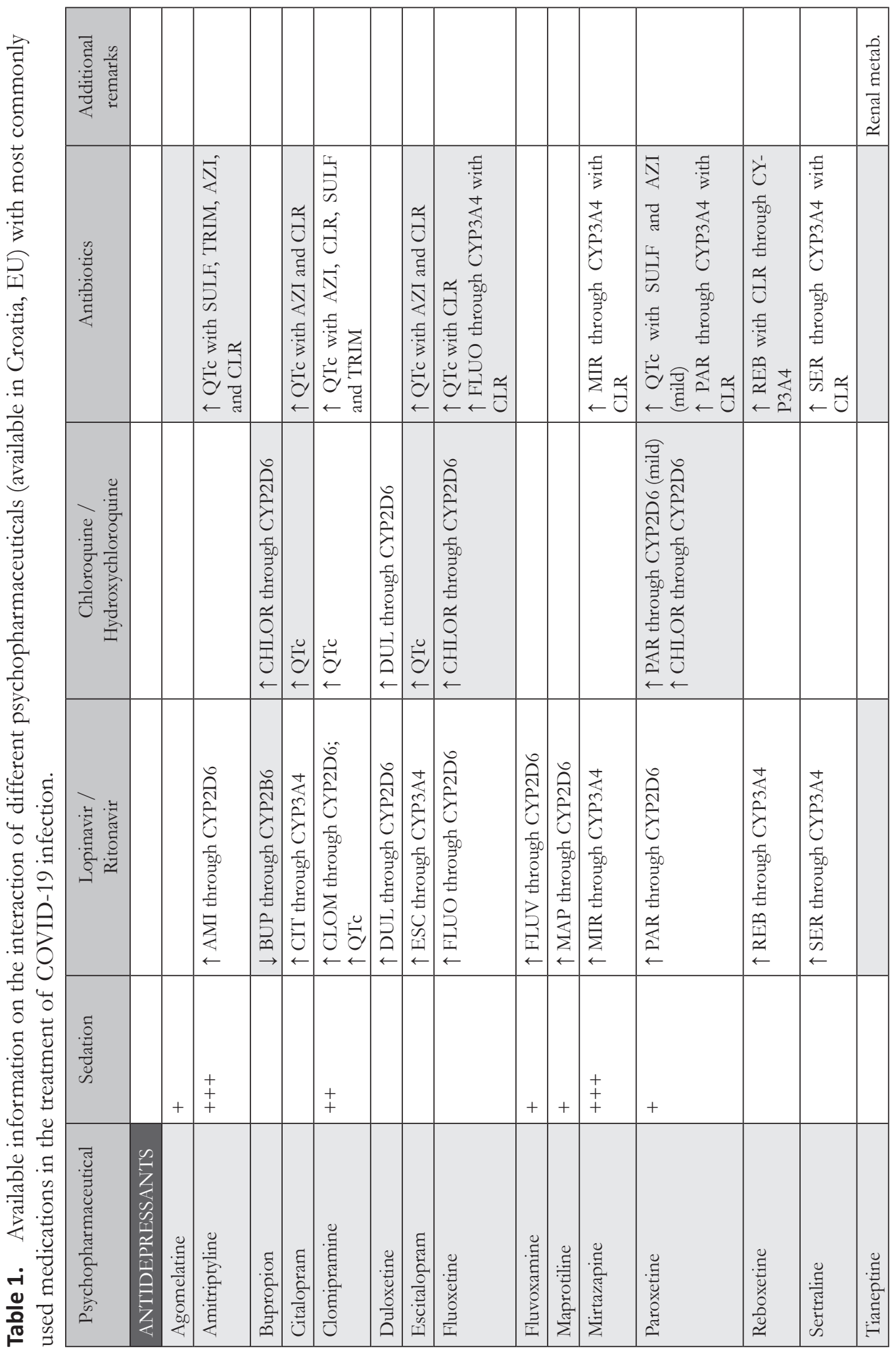




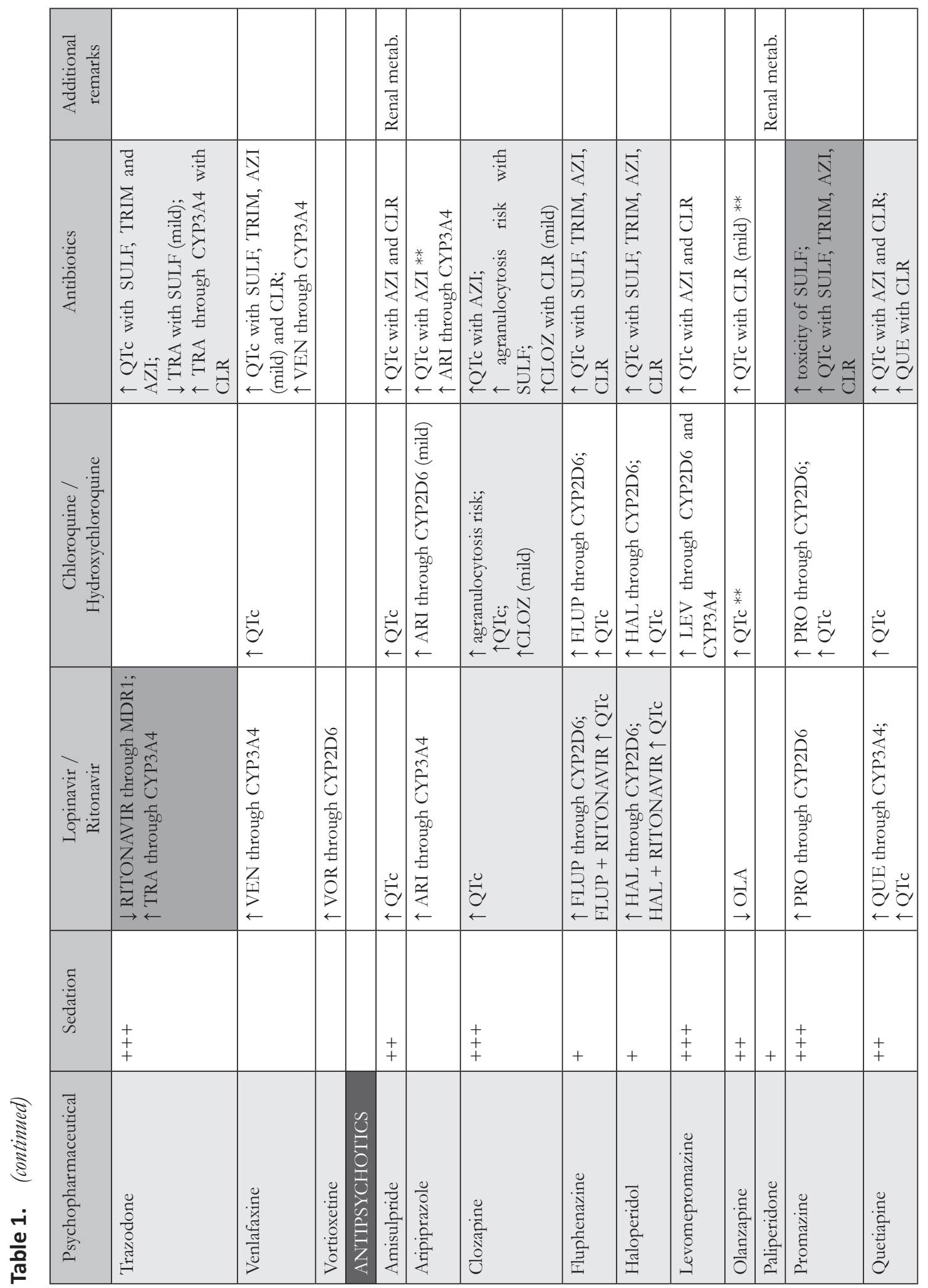




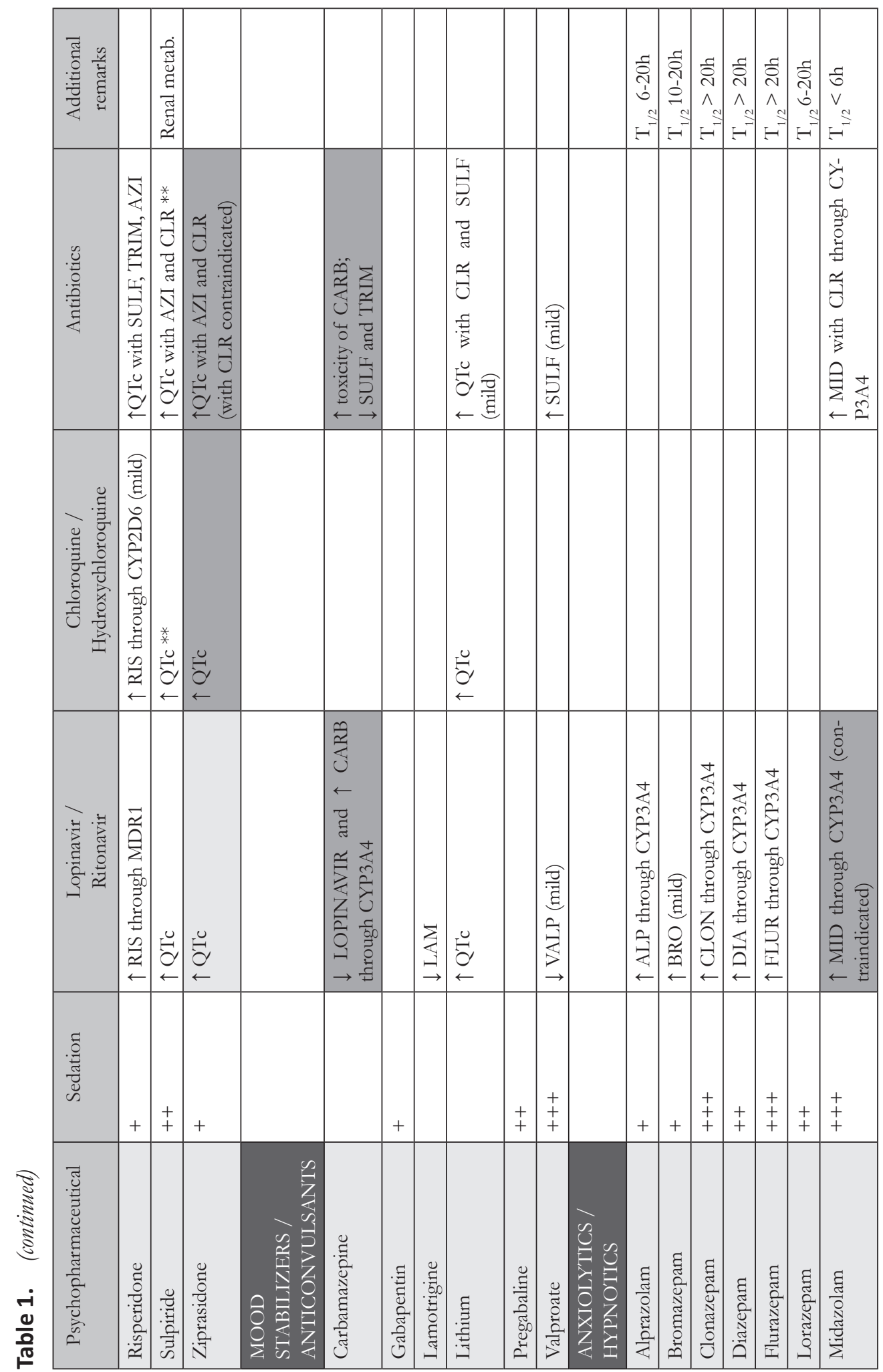




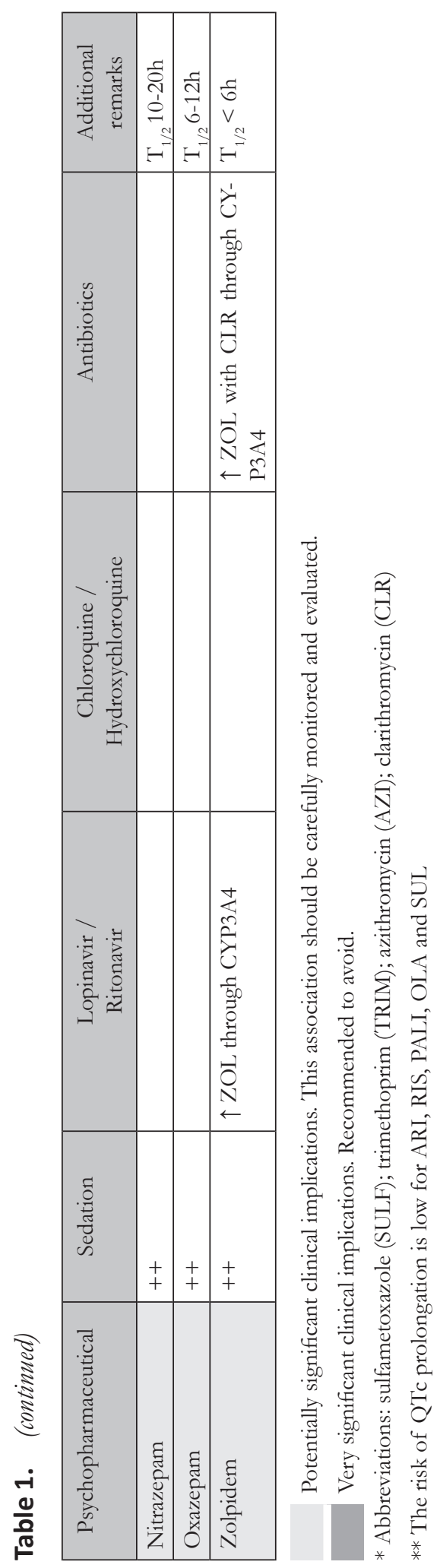


that schizophrenia spectrum disorders may be exacerbated or psychopharmacotherapy influenced by the infection alone. Be that as it may, caution should be exercised in patients with schizophrenia or other psychotic disorders with pulmonary comorbidity (e.g. COPD), as it has been reported earlier that administration of antipsychotics (especially higher dosages) increases the risk of acute respiratory failure. Similarly, the elderly and patients with comorbidities (chronic respiratory diseases, but also cardiovascular diseases, diabetes and malignancies) have the highest risk of developing a more severe COVID-19 clinical picture, often warranting respiratory support. Taking into account that there is a considerable number of patients with these comorbidities in the population of those suffering from schizophrenia and other psychotic disorders, it is urgent to follow the recommendations of the Croatian Institute of Public Health. Particular attention should be paid to smokers who are more prone to develop severe COVID-19 clinical presentations. It should be noted that the percentage of smokers among patients with psychotic disorders is higher than $75 \%$.

Should patients in remission be advised to stay home and not report to the hospital?

Patients in remission should not be required to attend regular check-ups, but to wait for the improvement of general conditions and renewal of outpatient psychiatric services. In other words, it is necessary to continue to adhere to earlier recommendations, especially regarding the regular use of prescribed psychopharmacotherapy. Alternatively, it is possible to arrange a telephone consultation with a psychiatrist. Given the circumstances of the current pandemic, it is desirable to allow patients to work in their home environment, but this depends on the nature of their employment and should be agreed upon after consultation with the family doctor and employer. In any case, patients are advised to ensure that they have a satisfactory home supply of medicines that they regularly take in therapy, in order to ensure the recommended measures of physical distancing.

How to reduce the risk of COVID-19 infection in patients with schizophrenia and other psychotic disorders?

Given that the vaccine for COVID-19 has not yet been developed, the main way to prevent infection is to reduce exposure to the virus and therefore general preventative measures are recommended, as stated on the web pages of the Croatian Institute of Public Health: https://www.hzjz.hr/wpcontent/uploads/2020/03/Dodatne-uputeza-pojedince-kolektive-i-poslodavce.pdf and https://www.hzjz.hr/wp-content/uploads/2020/03/Stariji-i-ostali-osjetljivi-nakoronavirus-2.pdf

\section{Summarized recommendations}

1) Potential risk factors for COVID-19 infection in patients with schizophrenia spectrum disorders:

- Over 60 years old

- Patients who visit health facilities more often

- Travels or mass gatherings

- Smoking

- Patients with comorbidity of lung disease, diabetes, chronic renal or hepatic disease, endocrinological and metabolic disorders, malignancies and other diseases that further immunocompromise the patient

- Malnutrition

- Patients on immunosuppressive / immunomodulatory therapy 
2) Procedures related to diagnostics and therapy:

- According to currently available information, the risk of COVID-19 infection is not increased with the regular use of psychopharmaceuticals (all groups)

- It is recommended to continue current psychopharmacotherapy if the disease is in remission

- In case of worsening of symptoms or suspected relapse, it is necessary to contact the family doctor or psychiatrist in charge or to use emergency psychiatric services

- It is recommended to delay elective surgery and elective invasive treatment

\section{References}

1. Karlović D. Psihofarmakoterapija i psihijatrijske fizikalne metode liječenja. In: Karlović D, editor. Psihijatrija. Jastrebarsko, HR: Naklada Slap; 2019. p 541-66.

2. Ostuzzi G, Amaddeo F, Michencigh G, Fagiolini A, Imperadore G, Barbui C. Indicazioni pratiche sull'uso degli psicofarmaci in pazienti affetti da COVID-19 [Internet]. 2020 [cited March 31 ${ }^{\text {st }}$ Available from: www.siep.it.

3. Peitl V. Laboratorijska dijagnostika, farmakogenetika i farmakogenomika. In: Karlović D, Peitl V, Silić A, editors. Shizofrenije. Jastrebarsko, HR: Naklada Slap; 2019. p 211-40.
3) Procedures in case of symptoms of respiratory illness (cough, sneezing, sore throat, fever, shortness of breath):

- Stay at home (don't go to work, school, other collectives, larger family gatherings and public places)

- If there is a suspected infection with COVID-19, or if it cannot be safely ruled out, epidemiological services should be consulted and their instructions followed

- Call your chosen physician (telephone / email) regarding the possibility of organizing an emergency check-up. Avoid going to a healthcare facility unless your doctor advised you differently

- In an emergency, call 112 or 113 (new call centre for any coronavirus questions)

4. Silić A, Karlović D. Mehanizmi djelovanja antipsihotika. In: Karlović D, Peitl V, Silić A, editors. Shizofrenije. Jastrebarsko, HR: Naklada Slap; 2019. p 255-90.

5. Taylor DM, Barnes TRE, Young AH. The Maudsley Prescribing Guidelines in Psychiatry 13th Edition. Chichester, UK: Wiley-Blackwell; 2018.

6. WHO. Guidelines for the management of physical health conditions in adults with severe mental disorders [Internet]. 2018 [cited March 31 ${ }^{\text {st }}$ ] Available from: https://www.who.int/mental_health/evidence/guidelines_physical_health_and_severe_ mental_disorders/en/ 
